\title{
ACTION for wilderness
}

If you are a dedicated, traditional-thinking forester who can't see the people for the trees or the value of uncut forests, read this. It is a suggestion that you attend the next Biennial Wilderness Conference, particularly if held in the eastern United States. Furthermore, the enthusiasm, drive, dedication and the ultimate measuring stick — results — of the delegates' efforts paled by contrast the usual CIF meeting or the results achieved by any of its committees or annual meeting resolutions.

The 12th Conference, sponsored by the Sierra Club in cooperation with the Wilderness Society and held last September in Washington, D.C., was the first one to be held in eastern United States. Previous meetings have been in San Francisco. As a result the word "wilderness" took on a new dimension. Indeed, the tenor of the meeting clearly revealed that the major issues in the east are environmental degradation and recreational opportunities and not "wilderness" in the classic sense. This is not to say that wilderness issues of the west were not real or vital to the delegates, but rather that their current concerns were strongly focused on the impact that the burgeoning population and industrialization are having on the natural landscapes of eastern United States and on the quality of their lives.

Discussion on the Wilderness Act of 1964 in the first portion of the program was extremely lively and speakers representing the various renewable resources agencies of the federal government came under heavy fire. John McGuire, Associate Chief of the US Forest Service and Richard Griswold, Chief, Division of Legislative Coordination and Support for the National Park Service, attempted to justify their Services' lack of progress in reviewing, in an alloted 10 -year period, about 45 million acres in national parks and national forests to determine their suitability as potential wilderness areas as required by the Wilderness Act, and an additional 6 million acres subsequently proposed by conservation groups. The reasons advanced by the two speakers were rather weak, and subsequent comments from the floor by junior members of these two services tended to support the critics, led by environment lawyers Arnold Reitze Jr. and Brock Evans. On this issue the generation gap seemed more like an abyss.

The major cause of the conflict between the federal renewable resource agencies and the advocates of wilderness lay in the interpretation of the term "wilderness" as set out in the Wilderness Act. The renewable resource agencies interpreted wilderness areas as pristine areas; areas from which modern man has been totally absent. Not surprisingly the agencies use this interpretation as it is largely the one which has been espoused by the Sierra Club in wilderness conflicts in western United States. However, in the east, this restrictive definition has worked against those who are attempting to have conserved small enclaves (e.g. 5,000 acres) of land relatively undisturbed by man, areas which support trees and wildlife and which can be utilized by urban recreationalists. Eastern wilderness advocates were willing to accept second growth stands, areas that are criss-crossed with extraction roads; in one case, an area with an old abandoned railway is being sought. Indeed, some eastern wilderness advocates are soliciting the general public's support by adopting the policy that proposed wilderness areas "will be open for hunting, hiking, fishing, primitive camping and other outdoor activities"; only cutting and mining are obvious exclusions.

Holding of the Conference in the east resulted in, or perhaps exposed, a schism in the rank and file. Indeed, it would appear that the conservationists of eastern United States and wilderness advocates of western United States may have hurt their own cause by this apparent contradiction - a contradiction which seems to be based more on scale than ideology, but one which the federal renewable resource agencies are effectively exploiting at this time.

The second half of the program covered a broad spectrum of conservation activities including opportunities and current campaigns for the establishment and preservation of natural areas (complimentary comments were paid to the SAF's efforts in this endeavour); coastlines and wetlands; wild, scenic and recreational rivers; and forested recreational lands.

The eastern wilderness advocates were by and large campaigning for the conservation of the few remaining natural and potential recreational areas. They were, in their view, fighting for the survival of man in an almost overwhelming technological society; a society which has been pushing industrial growth at any cost and which has been stressing quantity in life rather than quality of life. Similar resource battles are now being waged in Canada (e.g. Niagara Escarpment, Algonquin and Quetico Parks, Fraser River, etc.). The conflicts in Canada, however, are not of the same magnitude; firstly because we do not have the same population and industrial pressures, and secondly because a large number of provincial and national parks have been established and more are planned.

The rank and file of the Sierra Wilderness Clubs were obviously dedicated, capable of using the democratic system effectively, able to win over key elected representation and could boast about an impressive list of victories, including the Presidential Order stopping the Florida Cross-State Barge Canal. Indeed, the construction of the Barge Canal by the politically strong U.S. Corps of Engineers was stopped by "Three old ladies in tennis shoes.".

Taken from a report by R. M. WALDRON of the Canadian Forestry Service, Ottawa, and one of approximately 700 delegates at the Conference. 